\title{
EFL SPEAKING PRACTICE IN DISTANCE LEARNING DURING THE CORONAVIRUS PANDEMIC 2020-2021
}

\author{
Reima Saado Al-Jarf ${ }^{1}$ 迥 \\ ${ }^{1}$ King Saud University, Riyadh, Saudi Arabia
}

Received 6 July 2021

Accepted 16 July 2021

Published 31 July 2021

CorrespondingAuthor

Reima Saado Al-Jarf, reima.al.jarf

@gmail.com

DOI 10.29121/

granthaalayah.v9.i7.2021.4094

Funding: This research received no specific grant from any funding agency in the public, commercial, or not-for-profit sectors.

Copyright: (C) 2021 The Author(s). This is an open access article distributed under the terms of the Creative Commons Attribution License, which permits unrestricted use, distribution, and reproduction in any medium, provided the original author and source are credited.

\section{ABSTRACT}

Students at languages and translation departments at Saudi universities take listening and speaking courses. Before the pandemic, the students used to complete the activities in the textbooks which required them to engage in many real-life, face-to-face individual and/or collaborative small-group activities in the classroom such as role-playing, dramatization, inviting a guest, conducting interviews and others. However, due to the Coronavirus Pandemic, there was an emergency shift to distance learning at Saudi universities starting March 2020 onwards, where all courses are being delivered online. Several platforms are being used in distance education such as Blackboard, Zoom, Microsoft Teams and others. The current study explores the types of online speaking activities that a sample of college instructors at some language and translation departments are currently using in distance education and how they engage students online in the absence of face-to-face activities, interaction, and communication. Survey results showed that EFL college instructors are using a variety of online speaking activities such as: (i) assigning a topic which the students research and prepare at home and then give an online oral presentation about it online through the platform; (ii) using online debates about some issues; (iii) answering problem-solving questions; (iv) student-created podcast on a topic of their choice and publishing them in a Speaking Center on Twitter; (v) combining listening and speaking activities; (vi) using Vicaroo, a free online audio recording creator to record conversations and presentations; (vii) using the Kahoot app and others. Students and instructors' views on the effects of the online speaking activities on students' speaking skill development in the distance learning environment are reported.

Keywords: Speaking Activities, Speaking in EFL, Distance Learning, Distance Education, Coronavirus, Covid-19, Student Engagement in Distance Education, Student-Teacher Communication 


\section{INTRODUCTION}

Students majoring in English language, translation, linguistics, and literature at Saudi universities take listening and speaking courses. Before the CoronavirusPandemic, which started early 2020, students enrolled in speaking courses used to complete the activities in the textbooks which required them to engage in many real-life, faceto-face individual and/or collaborative small-group speaking activities in the classroom such as role-playing, dramatization, inviting a guest speaker to the classroom, conducting interviews, debates, oral presentations in front of their classmates, and others.

However, due to the Coronavirus Pandemic there was an emergency shift to distance learning (DL) at Saudi universities starting March 2020 onwards. All courses are being delivered online. Several platforms are being used in DL such as Blackboard, Zoom, Microsoft Teams and others. In the Spring semester 2020 AL-JARF (2020a) , conducted a study with a sample of students and instructors at a sample of colleges of languages and translation in Saudi Arabia and found that 55\% of the students and instructors surveyed were dissatisfied with DL, found it ineffective and frustrating and preferred in-class face-to-face instruction. 59\% of the students had difficulty understanding online lectures. The students indicated that their instructors used the same class material without adapting it to DL. No supplementary online material or resources were added. To $58 \%$ of the students, DL was a lot of hard work. $69 \%$ had problems communicating with their instructors and classmates. They preferred lecture recordings to attending live lectures as they found the latter boring.

Likewise, $64 \%$ of the instructors reported that many students were not interested in online learning, in doing assignments, refused to give oral presentations, did not ask questions as it was the case in face-to-face instruction, did not participate in online class discussions and did not do assignments. They were not enthusiastic, were demotivated and disappointed. There was little interaction in the DL environment. In addition, $57 \%$ of the instructors revealed that DL was new to them and required a new mode of teaching and learning with which they were not familiar. They did not know how to use the platform tools such as the white board, and how to adapt the course material to the new emergency online teaching environment. 63\% found it difficult to communicate with a large number of students enrolled in their course and give feedback to students individually.

Moreover, in Spring 2020, some students did not have devices and Internet to access their online courses. $83 \%$ of the participants reported that the Internet was slow, and they had difficulty logging into the DL platform. No technical supportwas available to the instructors and students during online classes and the technical support staff did not respond to their needs and did not solve Blackboard and Internet connection problems quickly. The instructors received no academic support to help them prepare online teaching material, activities, and assignments Al-JARF (2021b). 
In the Summer and Fall 2020, Saudi universities have taken numerous steps towards solving platform problems, improving Internet connectivity, helping students with no devices and Internet access, offering pedagogical training and support for instructors, and providing good technical support.

Since the development of the speaking skill requires practice, the present study aims to explore the types of online speaking activities that a sample of college instructors at some language and translation departments at Saudi universities are currently using in distance education in the Fall 2020 and Spring 2021. It aims to find out how instructors engage students online in the absence of face-to-face interaction and activities.

Finding of the current study are significant for English language instructors at Saudi university especially those who teach speaking courses. They will raise instructors' awareness of the types of effective online speaking activities that their colleagues are using and which they can adopt in distance speaking courses and guide them in how they can engage students.

\section{LITERATURE REVIEW}

A review of the literature showed that research investigating how the speaking skill is practiced by college students in the context of distance and online education is limited. A study by Volle (2005) investigated speaking skilldevelopment in an online DL course by 19 first-semester students learning Spanish as a second language (L2). The researcher assessed oral skill development in Spanish in a strictly online course based on students' pronunciation production in two recorded speaking activities and two real-time conversations. The students created two voiced audio e-mails each week over the whole the semester. They read texts aloud and completed grammardrills. Audio e-mails were compared at the beginning and at the end of the semester. In addition, the students participated in two Internet-based oral conversations with their instructor using MSN Messenger. Results showed sig- nificant gains in oral skill development in Spanish.

In Malaysia, Murugaiah (2016) used the Pecha Kucha (PK) presentation format to enhance oral presentation skills in L2 students at Universiti Sains Malaysia. Thirty distant students worked in groups and completed a task-based activity using the PK format in which the students used twenty slides containing visuals with minimal text presented in twenty seconds. Interview reports and the researcher's observations showed that the PK format is effective in supporting collaborative learning and fostering oral presentation skills in L2, but it posed challenges to students with low proficiency levels. To maximize the benefits of $\mathrm{PK}$, the researcher suggested the inclusion of more pedagogical support and training.

To develop adult learners' oral communication skills in EFL, Castillo (2016) used the virtual world of Second Life and a distance learning course platform. The researcher found that the virtual world of Second Life played a significant role 
in improving adult learners' listening and speaking skills. Although some online course platforms are enriched with interactive multimedia tools and dynamic content to facilitate learning, these tools imposed some challenges for learners who lacked digital skills and who were not familiar with the platform. The researcher concluded that utilization of different web-based technologies in language learning can be a useful strategy in enhancing students' engagement, teaching practices, and complementing the interactive aspects of these tools Castillo (2016).

In Australia, distance students enrolled in a university preparatory program chose a topic, set an audience, gave an oral presentation, and reflected on their experience. The students' responses via portfolio reflections and interviews indicated that this activity fulfilled their needs and that oral presentations were a meaningful and transformative experience McDougall and Holden (2017).

In a study by Galindo et al. (2020) , engineering students individually created a video in which they explained the solution to one of their homework-assignments. Following the video production, the students received feedback using an assessment rubric. Then, they produced a second version of the video for which they were assessed for the overall mark. Findings of the study showed that this activity helped the students improve their ability to give oral presentations.

Further studies in the literature focused on how some specific speaking skills are developed in DL. For example, Martin (2020) examined how distance language learners' pronunciation skills develop with and without targeted pronunciation training during the first semester of language instruction at the university. For that purpose, the researcher designed a computer-assisted method of pronunciation instruction and tried it for one semester with a sample of 67 distance students learning German as L2 online. The results showed that distance students who received targeted pronunciation training improved significantly and outperformed students in the control group who did not receive such training on measures of perception and production accuracy.

As part of the "Spanish Without Walls" program, Blake et al. (2008) examined a first-year language course offered at the University of California-Davis in both DL and hybrid formats. The "Spanish Without Walls" course consisted of materials on CDROM/DVD, content-based webpages, synchronous sound chat and text chat formats. To assess the effectiveness of the treatment, the researchers compared face-to-face and DL students who took a 20-minute "Versant for Spanish" test, delivered by phone and automatically graded. The researchers found that face-to-face, hybrid, and distance L2 students developed comparable levels of oral proficiency in their first year of language study.

Finally, the literature review showed no studies that explore speaking activities that EFL instructors at Saudi universities are using in the DL environment especially during the Coronavirus Pandemic. Therefore, this study aims to fill a gap in this area and shed some light on how EFL instructors and students at a sample of Saudi language and translation departments are coping with the emergency DL language 
learning environment, particularly how they are developing students' oral skills.

\section{DATA COLLECTION \& ANALYSIS}

\subsection{SUBJECTS}

Subjects of the current study consisted of 25 female university instructors teaching EFL at 5 Saudi universities: King Saud University, King Abdul-Aziz University, Umm Al-Qura university, King Khalid University, and the Saudi Electronic University. 45\% of the instructors have a Ph,D. and 55\% have an M.A. degree in TESOL, Linguistics and English Literature. They all teach speaking to students enrolled in translation, linguistics, or literature programs at those 5 universities. In addition, 50 female students enrolled in different levels of speaking courses were selected from the sample departments at the 5 universities. About $55 \%$ of the students in the sample were freshman.

\subsection{DATA COLLECTION}

It was not possible to get students' marks in face-to-face speaking courses before the pandemic and marks of students enrolled in online speaking courses offered during the Spring 2020 and Fall 2021. Therefore, comparisons of the face-to-face speak- ing activities and online speaking activities and the effect of online activities on students' speaking skill development are based on students and instructors' responses to questionnaire-surveys sent to them via WhatsApp.

The instructors' questionnaire-survey consisted of open-ended questions that asked the instructors about the following: (i) the kinds of online English speaking activities they have been using in the Fall 2020 and Spring Semester 2021; (ii) benefits and shortcomings of teaching speaking via DL; (iii) how instructors engage, encourage and support the students in online speaking courses; (iv) course materials and teaching techniques used in online speaking instruction; (v) attendance, homework, participation, self-efficacy and level of perseverance in DL speaking courses; (vi) interaction and communication between students and instructors in the DL speaking courses; and (vii) how feedback is provided by instructors and classmates.

Similarly, the students' questionnaire-survey consisted of open-ended questions that asked the students about their experience practicing DL English speaking and their reaction to the DL speaking activities, and whether they prefer to continue to practice speaking online after they return to face-to-face instruction after the Pandemic and why.

\subsection{DATA ANALYSIS}

Responses to the instructors and students' questionnaire-surveys were analysed qualitatively as it is more important to report and describe the kinds of speaking activities used by the instructors rather than reporting the percentages or frequen- 
cies of instructors using the same activity and students giving the same response.

\section{RESULTS}

\subsection{TYPES OF SPEAKING ACTIVITIES USED BY THE SAMPLE}

\subsubsection{ORAL PRESENTATIONS}

Almost all instructors in the sample indicated that the students give oral presentation about a topic chosen by the instructor and sometimes by the students themselves. A week before the online class session, the instructor assigns a topic which the students research, read about and prepare at home, then each student gives an oral presentation about the topic in 3-4 minutes while the instructor and the rest of the students are listening to and/or watching on the platform such as Zoom. The students may use a PPT, a picture or any media of their choice. The instructor corrects the students' pronunciation and grammatical errors and helps with the vocabulary that the students do not know. However, most instructors reported that the students make very few comments on their classmates' presentations.

As for the source of speaking topics, the instructors reported that few speak- ing topics are based on the textbook, but most are selected by the instructors with few suggestions from the students. The following are examples of speaking topics selected by the instructors:

- What does "challenge" mean to you? Define the word and support your answer by answering the following: (i) What are some of the challenges that you have faced when you first joined the university? (ii) How did you manage these challenges? (iii) How can these challenges improve you as a university student?

- Explain the meaning of the following quotations in your own words: (i) "The roots of education are bitter, but the fruit is sweet." -Aristotle. (ii) "It doesn't matter how slowly you go as long as you don't stop." -Confucius. (iii) "Love all, trust a few, do wrong to none." -William Shakespeare. (iv) "All that I am, or hope to be, I owe to my angel mother." -Abraham Lincoln. (v) "A gram of blood is worth more than a kilogram of friendship." -A Spanish Proverb

- What does family mean to you? Define the word and support your opinion by answering the following: (a) How do members of a family support each other? Give examples. (b) What does this quote mean "Family is like branches of a tree. We all grow in different directions; yet our root remains as one."? (c) In your opinion, in what ways do Western and Eastern families differ?

- What does "sibling" mean to you? Define the word and support your opinion by answering the following: (a) What are the advantages and disadvantages of being the eldest/youngest sibling? (b) A Vietnamese proverb says: "Brothers and sisters are as close as hands and feet." Explain. (c) Is sibling rivalry positive or negative? Explain. 
- Give a short presentation about banning smoking in public places. Explain the reasons for banning smoking and effects of smoking on people's health.

- What are the advantages and disadvantages of online classes? Explain your answer by mentioning at least two pros and two cons. State your opinion about your own experience with online learning.

- Office workers in a marketing agency did not do well on the yearly physical examination. They must decide what can be done to improve their physical fitness. After a long discussion, it was decided to educate workers on the benefits of doing sports. What is your advice to them?

Since different platforms are currently used in DL at Saudi universities such as Blackboard, Zoom and Microsoft Teams, students' presentations are recorded for later reference. Students who miss an online class may replay the recording. Some students like to replay their own recording at home to find out how their performance was and to re-listen to the instructor's corrections.

In addition, at King Abdul-Aziz University, speaking instructors use Vocaroo, a free online audio recording creator (voice recorder), to record conversations and presentations in speaking courses as it is a quick and easy way to share voice messages over the interwebs (Figure 1).

\subsubsection{ANSWERING PROBLEM-SOLVING QUESTIONS}

This is the second most popular activity. It is similar to the oral presentations described above. The difference is only in the speaking topics selected. Here, the students may propose solutions to educational, social, medical, environmental or political issues with or without prior preparation at home such as:

- Solving the digital gap during Covid-19

- Creating new jobs for the Covid-19 era

- Finding solutions to unemployment caused by Covid-19

- Global warming

- Food waste

- Refugees

- Combating terrorism

- How to entertain children at home during the Covid-19lockdown?

\subsubsection{ONLINE DEBATES ABOUT SOME ISSUES}

This is the third most common activity. Here, the students are divided into two teams with contradictory points of views on an issue. Students in each team try to convince the audience with their point of view. Some of the debate topics given are: 
- Should we teach English to children under the age of 6 ?

- Is distance learning a must or a luxury?

- Does educational reform start from the teacher or the curriculum?

- Is education after Covid-19 going to be the same as before Covid-19 or different?

- Which one is more effective face-to-face or distance education?

- Is the grammar-translation method good for teaching English to beginners?

- Do you encourage people to take the Covid-19 vaccine or not?

\subsubsection{COMBINING LISTENING AND SPEAKING ACTIVITIES}

Since some EFL students take courses that focus on both listening and speaking as it is the case at the College of Languages and Translation, King Saud University, instructors who teach such courses have the students listen to an audio of a lecture or conference presentation, then perform an oral task after they listen to the audio, as in the following examples:

1. Listen to the lecture about international advertising. You will listen to the audio twice.

2. Listen to the lecture and identify the 6 ways that sports benefit the human mind. Take notes of the 6 benefits.

3. You are going to listen to a conference presentation called "The Science of Fear". In this presentation, the speaker discusses different types of fear, the body's reaction to fear, and the purpose of fear. You will listen to the audiotwice.

4. Listen to different people talking about how noise affects their concentration.

5. Listen to a teacher giving students advice for exams. You'll listen to the audio twice.

6. Listen to Peter talking to his teacher Ken about his studydiary.

After the students listen to the audio, they answer auditory comprehension questions, summarize the content of the audio, or give the main ideas and important details orally.

\subsubsection{KAHOOT}

Kahoot, an app that is like a contest in which two teams compete with each other. The students play, create and host quizzes. They create and host their own learning games to boost knowledge, retention and develop 21st century skills. Few instructors in the sample use Kahoot in combination with online debates.

\subsubsection{STUDENT-CREATED PODCASTS}

Alecturer at the English Department, at King Saud University created a Speaking Center on Twitter where the students record, stream and/or upload their podcasts using 
the SoundCloud App for immediate discovery (Figure 2 ). The students choose the topics of their podcasts. They are all volunteers, and they create their podcasts once a week as an extracurricular activity. There is a total of 17 podcasts in the Speak-ing Center created by participating students. The following are examples of some student-created podcasts:

- The Effects Pets have on their Owners https://soundcloud.com/user-902447197/the-effects-pets-have-on-their

- The Stereotypes That College of Arts Students Face https://soundcloud.com/user-902447197/the-stereotypes-that-college

- Personal information security in the era of big data https://soundcloud.com/user-902447197/personal-information-security

- Code-switching: With or against, and why? https://soundcloud.com/user-902447197/code-switching-with-or-against

- Where Do Freshmen Go? https://soundcloud.com/user-902447197/podcast-1

- The Tales of Coffee https://soundcloud.com/user-902447197/the-tales-of-coffee

- Saudi National Day and How We Celebrate It https://soundcloud.com/user-902447197/saudi-national-day-and-how-we

- Academics and Pandemics: How to Stay Motivated While Studying at Home https://soundcloud.com/user-902447197/podcast-1

\subsection{STUDENT-INSTRUCTOR COMMUNICATION}

During the DL speaking class, the students communicate with their instructor, and in few occasions, make comments and/or ask questions via the platforms' chat or hand-raising tool. The students reported that after class, they mostly communicate with their instructors via WhatsApp. Some instructors form a WhatsApp group for each section or course they teach. Individual students may communicate with their instructors privately if they do not wish to ask questions or seek help openly.

\subsection{MOTIVATING THE STUDENTS}

Most of the speaking activities used to develop the students' speaking skills in the DL environment are student-centered and task-based. The students prepare the assigned topics at home in which case they have plenty of time to read about the topic, check the meanings of difficult words, summarize and/or synthesize information from different sources. They prepare their PPT, or any other audio-visual needed for the presentation. They can also rehearse at home before they give their presentations online. The students take their activities seriously and work hard because they are given marks for their assignment, each week. Contrary to DL during the first lockdown in Spring 2020 when marks allocated for classwork, projects and attendance were cancelled and only $20 \%$ of the course mark was allocated to final exams, in Fall 2020 and Spring 2021, the instructors were using formative assessment. Each online speaking class session, they evaluated each student's oral performance and gave marks for participating in the speaking activities and class atten- 
dance. Some instructors used an assessment rubric in which they allocate part of the total assignment mark to (i) generating ideas, (ii) fluency and good expression, and (iii) grammatical, pronunciation and lexical accuracy. The components of the assessment rubrics and marks allocated to them differ from instructor to instructor and from one type of speaking activity to another.

\subsection{STUDENTS' VIEWS}

Analysis of the students' responses to the questionnaire-survey showed that the online speaking activities were useful, helpful, fun and beneficial. Their speaking skills improved a lot as a result of preparing and rehearsing at home and the feedback given to them by their instructors. Although at the beginning of the semester, many students were shy, nervous and could not speak online, but at the end of the semester they gained self-confidence because of practicing speaking every week, and instructors' encouragement, and tolerance of errors. The online speaking sessions reduced their stress especially because they could turn their video off and just focus on listening and speaking, i.e., use audio only. Some of the students wrote:

- Ghada: the speaking practice is valuable. My speaking skills have improved as a result of weekly assignments, preparation and presentations.

- Hanoof: the teacher was kind, patient, and paid attention to eachstudent.

- Sara: the teacher provides valuable feedback. She corrects my grammatical and pronunciation mistakes.

- Moudi: the online speaking practice is beneficial. I am not as shy and nervous like when I presented in the classroom in front of my classmates. When I speak online, I turn my video camera off which makes me less anxious.

- Dalal : practicing speaking and listening on the DL platform helps me focus better as the class session is noise free and there are no distractions. I go online in the convenience of my home. Turning my webcam off helps me focus better as well.

- Maha : the hand-raising tool is useful because I can use it to ask questions.

Other advantages of online speaking courses reported by the students were that they could join the platform through their smart phone or laptop. They did not have to commute to the university. They could replay the recording of the class session whether for their own presentation or other students' presentations on Zoom or Vocaroo, especially if they miss a live speaking session. In face-to-face practice in the classroom, activities are not recorded.

However, some students indicated that online speaking activities are not like faceto-face speaking activities in the sense of community they feel with their classmates and instructor in the classroom because they take the course with students whom they never met before, i.e., students do not know each other. In the classroom, there is eye-contact, gestures, and more rapport which are absent in online speaking classes. They can also engage in some speaking activities such as role-playing and dramatizations which they cannot perform in DL as they cannot meet with some classmates 


\subsection{INSTRUCTORS' VIEWS}

Unlike online speaking classes during the lockdown in March 2020, some speaking instructors reported that in the Fall 2020 and Spring 2021, the students became more interactive, more attentive, and more interested in learning. Most speaking instructors in the study had a positive attitude towards the online speaking sessions. There was more engagement in the activities, interaction and communication among the students and their instructors because in Spring 2020, the university cancelled the marks allocated to classwork and attendance, the students were not efficient in using the platform, never had experience with DL, had problems with the platform and Internet connectivity. As instructors, they gained more experience in handling the different tools in Zoom, WebEx, Microsoft Teams and/or Blackboard as they had a chance to practice and thus became more familiar with the platform tools. They also learnt from colleagues who are more competent in using the DL platforms and teaching online.

However, in teaching speaking via Zoom, WebEx, Microsoft Teams, and similar applications, the instructors and the students could only hear each other's voices but not see each other's faces on the screen as both instructors and students turned their webcams off for social reasons

Another challenge that the instructors had is reading the questions in the chat while listening to students' presentations, in addition to responding to students' queries on WhatsApp. As the students stated in their responses, the instructors indicated that some face-to-face speaking activities cannot be performed online via the platform such as group role-play, dramatization and field trips.

\section{DISCUSSION}

Findings of the present study showed that speaking instructors at the sample institutions in the present study mainly used oral presentations, gave problem-solving questions, used online debates, student-created podcasts posted in a Speaking Center on Twitter, used Vocaroo to record students' presentations and Kahoot for contests and games. These kinds of speaking activities are different from those used in prior studies by Volle (2005) , Murugaiah (2016) , Castillo (2016) , McDougall and Holden (2017) , Galindo et al. (2020) , and Martin (2020) which used audio emails, Internet-based oral conversations with the instructor using MSN Messenger, computer-assisted pronunciation instruction, Pecha Kucha (PK) presentations, i.e., slides containing visuals with minimal text and presented in twenty seconds, Second Life, portfolio reflections, student-created videos and use of Internet-based material.

Unlike findings of a study by Murugaiah (2016) which reported that many student presentations were boring and did not enhance the students' oral presentation skills because the students generally read from text-heavy PowerPoint slides, students in the present study found the PPTs and other visuals very useful and helpful in following the presentation. They helped them focus and understand better as the presentations were followed by questions and they were given marks depending on 
the quality of their performance.

As in Murugaiah's study, it was noted that in the student-created podcasts posted in the Speaking Center, the students read, not speak. The lecturer who created the Speaking Center said that she is allowing the students to read because they are new to this kind of activity and might be apprehensive of speaking lest they should make mistakes. The author believes that reading is not speaking. When the students search for a topic and find information about it, they do not have to memorize it word for word. They should try to comprehend it, summarize and try to talk about it in their own words. They can use keywords or a list of brief points to help them remember the content and organize their ideas. They can start talking about short, easy and familiar topics and move on to longer and more difficult ones.

Contrary to Edwards (2021), instructors in the present study did not incorporate any public speaking instruction or training in online speaking sessions. Moreover, they did not incorporate any online videos, the flipped classroom strategy, mobile speaking apps or mobile audiobooks in online speaking practice. Viewers of and students participating in the Speaking Center did not make any comments on the students' podcasts.

\section{CONCLUSION AND RECOMMENDATIONS}

Although some of the speaking activities used by speaking instructors at the sample institutions in the present study are innovative in nature such as the Speaking Center on Twitter, use of Vocaroo and Kahoot, they are not all-inclusive. More engaging, interactive, and interesting speaking activities can be utilized in the DL environment during the Pandemic as follows:

- Integrating social media and live streaming apps such as Periscope and videoconferencing software such as Elluminate and Adobe Connect in class presentations and student-student and student-instructor interaction Al-JARF (2021d).

- Integrating mobile apps such as pronunciation apps, daily English lessons, podcasts and listening and speaking apps such as www.talkenglish.com, and apps for practicing auditory comprehension skills as in images 3, 4, \& 5 Al-JARF (2020b) ; Al-JARF (2012a).

- Using mobile audiobooks only, mobile audiobooks that combine listeningand speaking activities and/or mobile audiobooks that combine reading and speaking activities as in Images 6, 7 \& 8. The students can listen or read a mobile audiobook, then give a summary of or answer questions on its content orally AlJARF (2021e).

- A variety of online videos can be utilized to improve students' pronunciation and provide American or British accent training. The students can also watch some short videos, summarize the content or answer comprehension questions on the video orally Al-JARF (2012a).

- Since speaking is a productive skill, integrating participation goals in speaking instruction is significant because participation goal focus on student's involvement in social issues and civic affairs with which they are familiar and to which 
they can relate Al-JARF (2021b) . Examples of issues that students can talk about are: Street children, obesity, traffic jams, terrorism, problems/issues related to social media, conserving energy, unemployment among college graduates, coronavirus-related topics, and global warming.

- Integrating linguistic landscapes in speaking activities. Linguistic landscapes cover street signs, direction, warnings, names of places, tourist attractions and ads displayed in public spaces. The students can discuss the meaning of some English linguistic landscapes and their linguistic aspects orally Al-JARF (2021f).

- Reading multicultural children's literature and stories at home and giving a summary, answering questions, or commenting on the story orally Al-JARF (2015) , Al-JARF (2016).

- Providing the students with online public speaking and communication training which include: (i) Non-verbal communication: Posture, gestures, face and eye, voice; (ii) choosing and developing a topic; (iii) organization and support; (iv) practicing the speech; and (v) overcoming online presentation and digital communication fright Al-JARF (2007).

- Rather than correcting every pronunciation and grammatical mistake in the students' presentation, the students should speak for communication and not worry about pronunciation and/or grammatical mistakes. After a student's presentation, the instructor can give communicative feedback that focuseson meaning and highlight errors related to rules or skills under study in a particular session. Feedback should be provided on the presence and location of errors, but no correct forms should be given by the instructor. Self-correction and peer-correction should be encouraged based on prompts from the instructor Al-JARF (2021a).

- Using social media for oral and written communication between the instructors and their students such as Facebook, Telegram, WhatsApp, Twitter, and Instagram Al-JARF (2020c).

Finally, this study recommends that future studies investigate assessment techniques used by instructors in online speaking courses as opposed to those used in face-to-face speaking assessment and whether instructors have made any changes and adjustments in their online speaking formative and summative assessment. Since the students are going to be studying face-to face starting Fall 2021, studies that explore whether instructors and students prefer to continue to practice speaking online in combination with face-to-face speaking classes is open for further investigation by future research. 


\section{APPENDIX}

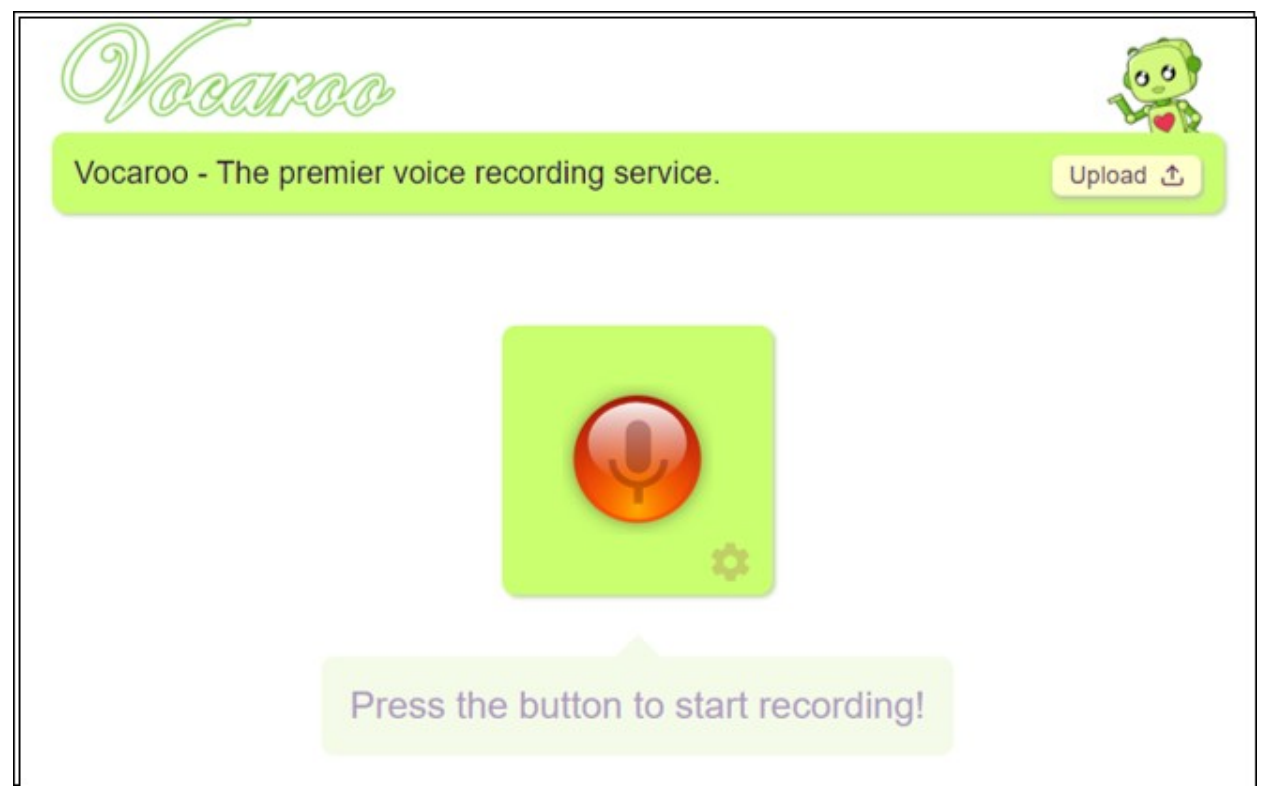

Figure 1 The Vocaroo Voice Recording Service

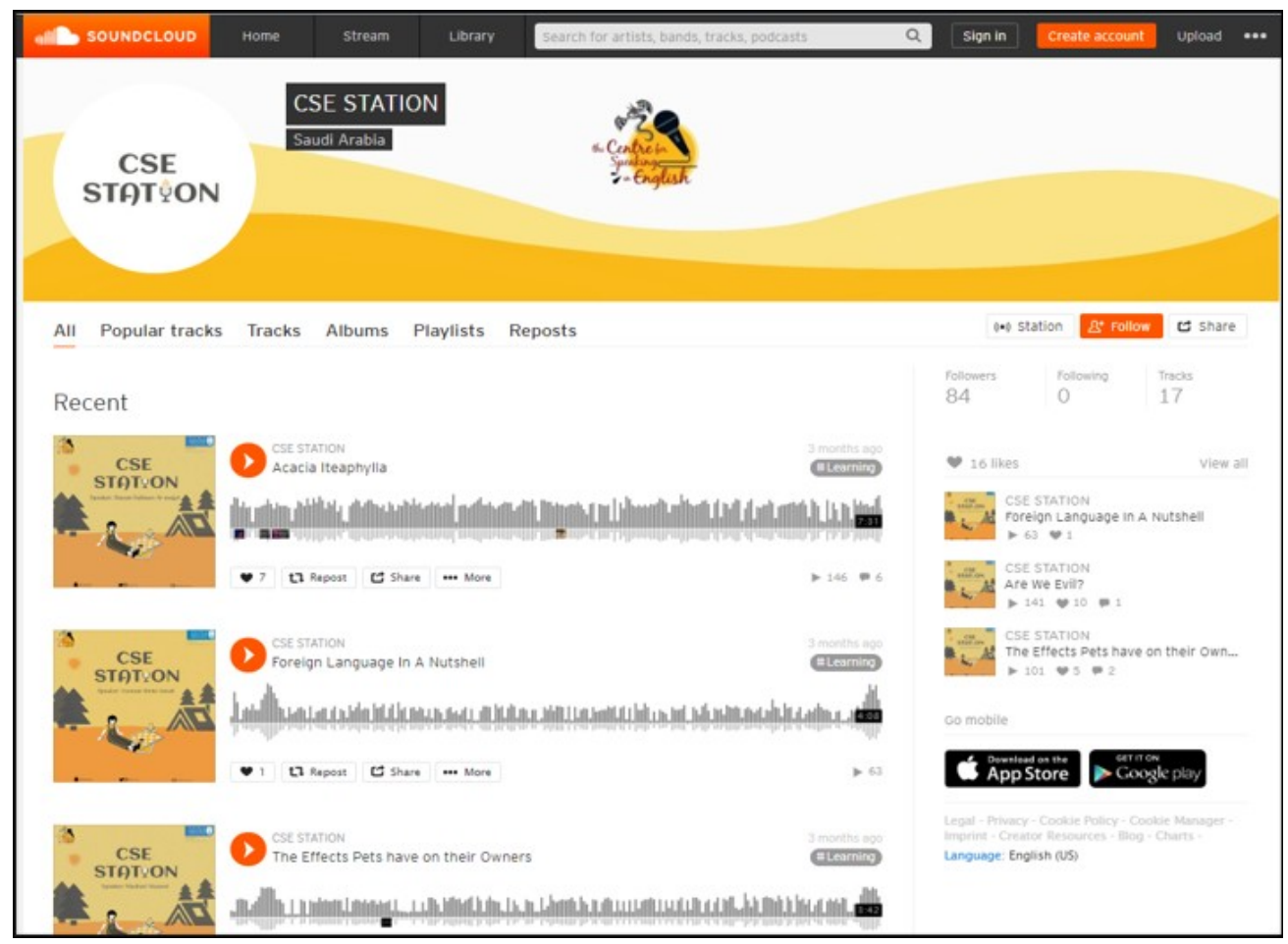

Figure 2 Sample Podcasts from the Speaking Center 


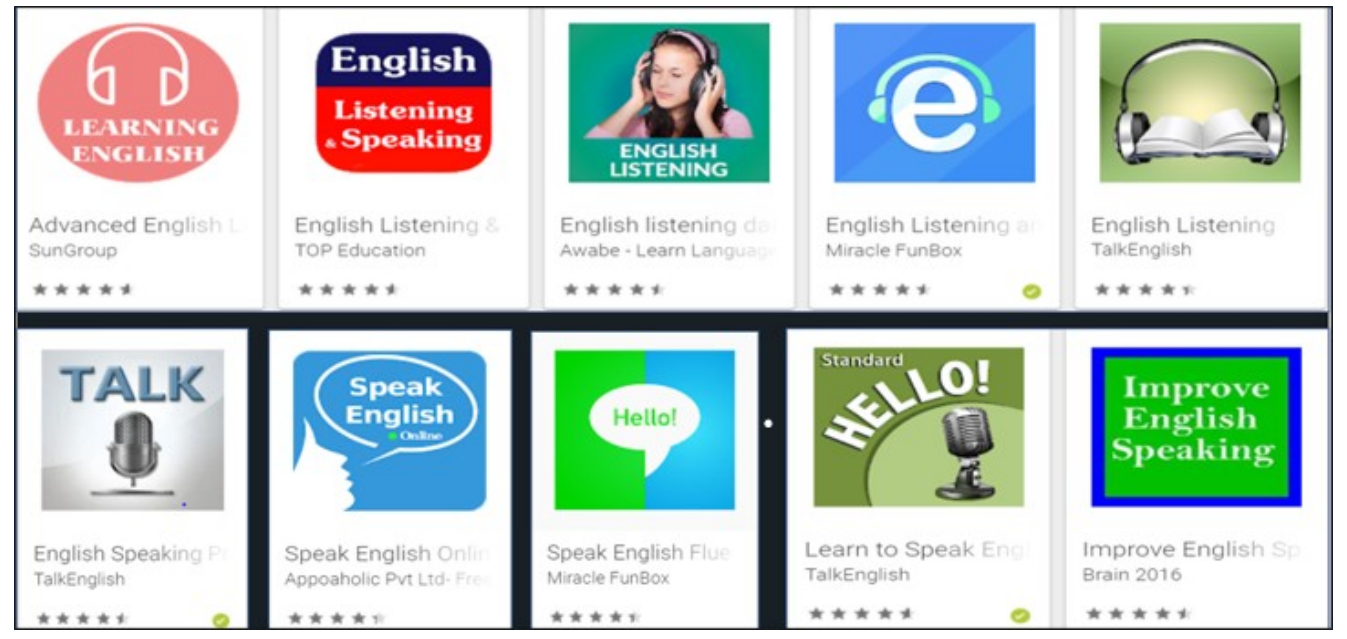

Figure 3 Mobile Listening Apps

English Pronunciaa
az-20 Apps

Figure 4 Pronunciation Apps

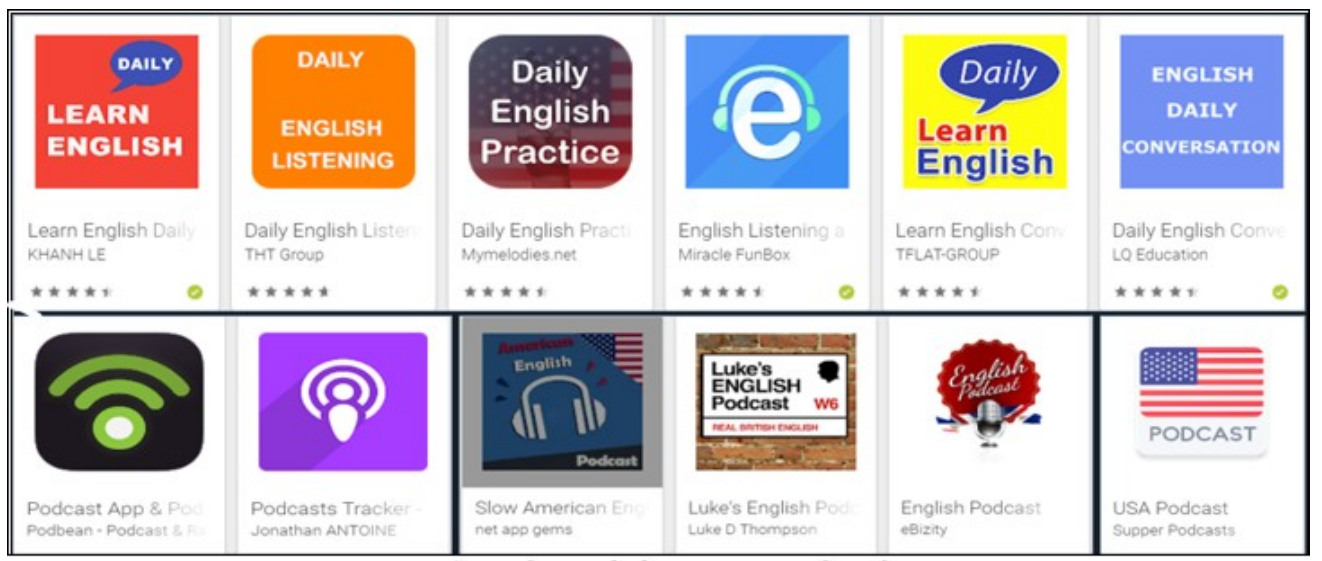

Figure 5 Daily English Lessons and Podcasts 


\begin{tabular}{|c|c|c|c|}
\hline Audiobooks Search & $\mathrm{n}_{\mathrm{Au}}$ & By Genre & \\
\hline 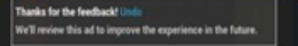 & Charles Dickens & Adventure & Ludio Books Free \\
\hline charles Dickens & Part Nr 1 & Advice & ES \\
\hline 1. Charles Dickens 200th & & Ancient Texts & \\
\hline $\begin{array}{l}\text { Anniversary Collection } \\
\text { Vol. } 1\end{array}$ & Part Nr. 2 & Animals & hMillic \\
\hline$x=1$ chanes Bickens librivox org & Part Nr. 3 & Art & \\
\hline $\begin{array}{l}\text { 2. Charles Dickens } \\
\text { G. K. Chestertion }\end{array}$ & Part $\mathrm{Nr} 4$ & Biography & dren's Classics! \\
\hline 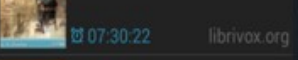 & $\begin{array}{l}\text { This audiobook is playing } \\
\text { from the litrivoxorog }\end{array}$ & Classics (antiquity) & $\begin{array}{l}\text { New Release Free } \\
\text { AundinRonks }\end{array}$ \\
\hline 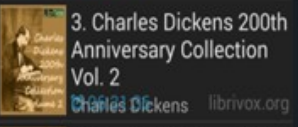 & $0: 00$ & Cookery & ह \\
\hline $\begin{array}{l}\text { 4. Charles Dickens 200th } \\
\text { SEARCH HISTORY }\end{array}$ & (4) 4. & $\begin{array}{l}\text { Economics/Political } \\
\text { Epistolary fiction }\end{array}$ & 5) 1 \\
\hline
\end{tabular}

Figure 6 Examples of Mobile Audiobooks

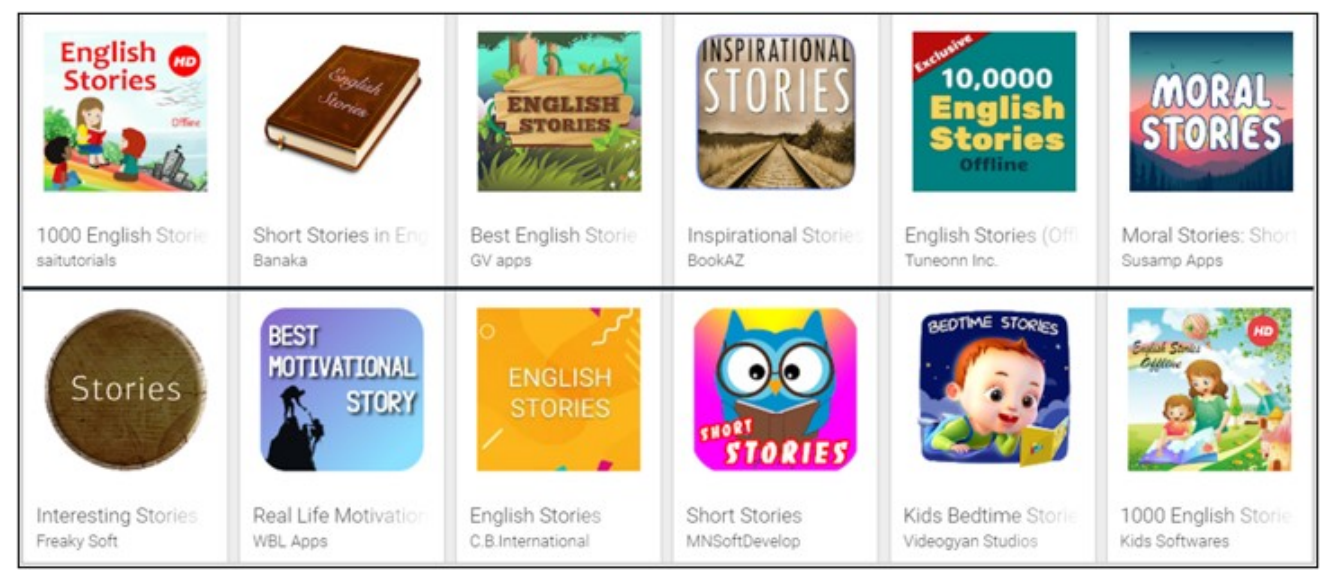

Figure 7 Combining Listening and Speaking Activities

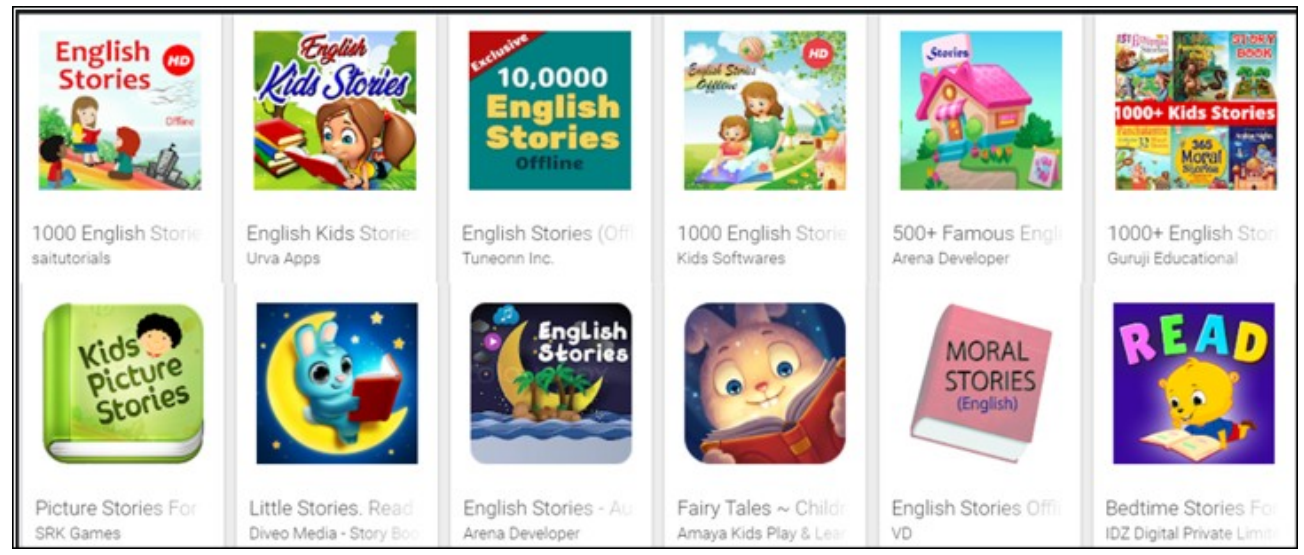

Figure 8 Combining Reading and Speaking Activities 


\section{REFERENCES}

Al-Jarf, R. (2007). From reticence to fluency. The international conference on task-based language teaching. Center for Language and Migration, University of Leuven, Belgium

Al-Jarf, R. (2012a). Mobile Technology and student autonomy in oral skill acquisition. In Javier E. Díaz Vera's "Left to My Own Devices: Learner Autonomy and Mobile-Assisted Language Learning”, 105-129. Emerald Group Publishing Ltd. https://doi.org/10.1163/9781780526478_007

Al-Jarf, R. (2012b). Online videos for specific purposes. Journal of Education and Social Research (JESR), 2(6), 17-21.

Al-Jarf, R. (2015). Enhancing reading and speaking skills in EFL through multicultural children's short stories. 7th International Conference Building Cultural Bridges (ICBCB), Almaty, Kazakhstan, April 23-24. ERIC ED610158.

Al-Jarf, R. (2016). Enhancing reading and speaking skills in EFL through multicultural literature. Asian Academic Research Journal of Social Sciences \& Humanities (AARJSH), 3(7), 288-298.

Al-Jarf, R. (2020a). Distance Learning and undergraduate saudi students' agency during the Covid-19 pandemic. Bulletin of the Transylvania University of Braşov Series IV: Philology and Cultural Studies, 13(62), 2, 37-54. https://doi.org/10.31926/but.pcs.2020.62.13.2.4

Al-Jarf, R. (2020b). Mobile apps in the EFL college classroom. Journal for Research Scholars and Professionals of English Language Teaching (JRSP-ELT), 4 (22),1-5.

Al-Jarf, R. (2020c). Communication among instructors and students via Twitter. In Irena Vassileva, Mariya Chankova, Esther Breuer and Klaus P. Schneider (eds.) The Digital Scholar: Academic Communication in Multimedia Environment, pp. 265-280. Frank \& Timme.

Al-Jarf, R. (2021a). A Model for communicative error correction in Saudi EFL freshman students' writing. i-Manager's Journal on English Language Teaching, 11(2), 32-41. https://doi.org/10.26634/jelt.11.2.17719

Al-Jarf, R. (2021b). Integrating participation goals in writing activities for EFL college students. Journal for Research Scholars and Professionals of English Language Teaching (JRSP-ELT), 23, 5. ERIC ED613141.

Al-Jarf, R. (2021c). Investigating equity in distance learning in Saudi Arabia during the Covid-19 Pandemic. The $17^{\text {th }}$ International Scientific Conference eLearning and Software for Education, Bucharest, Romania. Vol 1.

Al-Jarf, R. (2021d). Issues in using Periscope for live academic lectures during the Covid-19 pandemic. i-Manager's Journal of Educational Technology, 18(1), 15-25. https://doi.org/10.26634/jet.18.1.17711

Al-Jarf, R. (2021e). Mobile audiobooks, listening comprehension and EFL college students. International Journal of Research -GRANTHAALAYAH, 9(4), 410-423. https://doi.org/10.29121/granthaalayah.v9.i4.2021.3868

Al-Jarf, R. (2021f). Teaching English with linguistic landscapes to Saudi students studying abroad. Asian Journal of Language, literature, and Culture Studies (AJL2CS), 4 (3), 112.

Blake, R., Wilson, N. L., Cetto, M. \& Pardo-Ballester, C. (2008). Measuring oral proficiency in distance, face-to-face, and blended classrooms. Language Learning \& Technology, 12(3), 114-127.

Castillo, M. I. (2016). Using a virtual world as a communication space to supplement an online course platform for teaching oral communication skills to adult English as a second language learners. Ed.D. Dissertation, Texas A \& M University - Kingsville. ERIC ED596393.

Edwards, A. A. H. (2021). From TED talks to TikTok: Teaching digital communication to match student skills with employer desires. Basic Communication Course Annual, 33, Article 17, 336-341. 
Galindo, C., Gregori, P., Martínez, V. (2020). Using videos to improve oral presentation skills in distance learning engineering Master's degrees. International Journal of Mathematical Education in Science and Technology, 51(1), 103-114.

Martin, I. (2020). Pronunciation development and instruction in distance language learning. Language Learning \& Technology, 24(1), 86-106.

McDougall, J. \& Holden, H. (2017). The silence about oral presentation skills in distance and online education: new perspectives from an Australian university preparatory programme. Open Learning, 32(2), 163-176.

Murugaiah, P. (2016). Pecha Kucha style Powerpoint presentation: an innovative call approach to developing oral presentation skills of tertiary students. Teaching English with Technology, 16(1), 88-104.

Volle, L. (2005). Analyzing oral skills in voice e-mail and online interviews. Language Learning \& Technology, 9(3), 146-163.

\section{AUTHOR BIOGRAPHY}

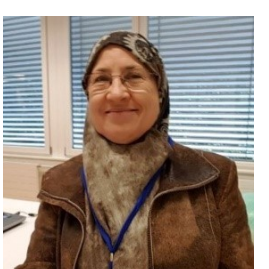

Reima Saado Al-Jarf is professor of ESL, ESP, and translation. She has 700 publications and conference presentations in 70 countries. Some of her articles are published in Web of Science and Scopus- indexed journals. She reviews Ph.D. theses, promotion works, conference and grant proposals, and articles for numerous peer-reviewed international journals including some Web of Science and Scopus-

indexed journals. She won 3 Excellence in Teaching Awards, and the Best Faculty Website Award at her university. Her areas of interest are: Foreign language teaching and learning, technology integration in education and translation studies. 